\title{
ЖАНРОВА ПАЛІТРА НОВИХ МЕДІЙ: СПЕЦИФІКА І КРЕАТИВНІСТЬ
}

\author{
Юліана Лавриш \\ Львівський національний університет імені Івана Франка, \\ вул. Генерала Чупринки, 49, 79044, Львів, Україна, \\ e-mail: newmedialnu085@gmail.com
}

У публікації представлено різновиди жанрової палітри нових медій, проаналізовано інструментарій та ефективність жанрів у творенні формату громадянської журналістики та демократизації медіа-простору. Автор дослідження окремо осмислює такі жанри, як: блог, мікроблог, стрім, подкаст, новина, лонгрід, а також представляє нові можливості мультимедійного інструментарію: тайм-лайн, сторіфай.

Ключові слова: жанри нових медій, блог, тайм-лайн, стрімінг, подкаст.

Традиційна журналістика містить чимало можливостей для обробки та передання інформації. Якщо ми текстуально працюємо з певною темою, то використовуємо жанри, які найкраще допомагають реалізувати мету журналіста. Безумовно, жанрова палітра - це своєрідний набір інструментів для журналіста, адже їхній формат, способи подання дозволяють доступно і креативно подати ту чи іншу інформацію, а жанри нових медій спонукають представити певну інформацію в мультимедійному спектрі. 3 цього випливає актуальність дослідження - у нових можливостях роботи із інформаційним простором, адже цифрові можливості дають змогу у специфічному поданні та обробці інформації. Нові медії представляють собою трансформацію старих і звичних підходів, яких ми звикли застосовувати у традиційних ЗМК, додаючи можливостей ще краще працювати з текстом, звуком, відео, представляючи собою мультимедійний простір і водночас вимір презентації особистості, яка прагне поділитися своєю інформацією зі світом. Знову-таки цифрові можливості дали змогу сформуватися самобутнім жанрам нових медій, деякі з них трансформувались із традиційних жанрів.

У межах дослідження ми використовували праці таких дослідників, як: Річард Крейг, Борис Потятиник, Юрій Залізняк, Марина Женченко, Тарас Назарук та інші.

Отож мета дослідження - це представити палітру жанрів нових медій, вказавши їхню ефективність і мультимедійні можливості.

Зазначена мета передбачає виконання таких завдань:

- представити палітру жанрів нових медій;

- охарактеризувати жанри нових медій у порівнянні із традиційними жанрами у ЗМK;

(C) Лавриш Ю., 2018 
• дослідити ефективність жанрів нових медій через їхні можливості;

- проаналізувати рівень популярності цих жанрів для користувачів нових медій;

- проаналізувати можливості журналістики Web 2.0, зважаючи на появу і функціонування жанрів нових медій.

Новизна дослідження полягає у жанровій різноманітності нових медій та їхнім новим цифровим можливостям для глибинного представлення контенту. Варто зазначити, що можливості веб-журналістики настільки швидко змінюються, що змінюються формати, популяризація та інструментарій жанрової палітри нових медій.

Одним із перших та найбільш популярних жанрів інтернет-простору є блог. Термін веблог (англ. weblog - веб-журнал) у грудні 1997 року запропонував Йорн Баргер, у 1999 році Пітер Мерхольц ввів скорочення блог (blog. Блог - це один із жанрів нових медій, де автор за допомогою тексту, зображення може висвітлити власну позицію на ту чи іншу тему. Варто зазначити, що блоги - це швидке оновлення інформації та позицій, водночас це вільне висловлення думок та суджень [2; с. 110].

Важливо, що у 2006 році в Інтернеті налічувалось всього близько 3 млн блогів, а до 2013 року ця цифра сягнула 152 млн. На основі запропонованих фактів можемо усвідомити для себе, наскільки це популярний жанр. Зважаючи на те, що спочатку блоги були представленням певного судження на ту чи іншу тему, таким собі приватним майданчиком для ділення позиціями із іншими на певних веб-платформах, сьогодні у мережевій журналістиці - це не просто вільний стиль, а самобутній жанр, що викликає довіру до автора в аудиторії, є авторитетним в інформаційному просторі. Кожен найбільш популярний веб-ресурс в Україні має окрему колонку з блогами - «Українська правда», «Zaxid.net», «День», «Ліга.net», а також інші ресурси. Важливо, що чимало блогерів, які представляють свої тексти на цих веб-ресурсах $\epsilon$ авторитетними особистостями в українському медіа-просторі. Власне, жанр блогу дозволяє зробити собі ім'я, навіть якщо ти не є професійним журналістом. Ось чому у світовій журналістиці $є$ ще один доволі потужний напрям - громадянської журналістики чи так званого медіа-активізму, коли позиційна особистість з допомогою інструментаріїв блогосфери має можливість не лише звернутися до суспільства, але й бути почутою в аудиторії.

Загалом основними ознаками блогу є авторський та суб'єктивований характер інформації, унікальність, власний стиль, розміщення публікакцій за хронологічним порядком, інтерактивність, доступність для широкої аудиторії, періодичне оновлення. Ці властивості притаманні усім блогам у загальному, та у кожного з видів є свої особливості функціонування. Російська дослідниця Наталя Прудка пропонує класифікувати блоги за типом знакових систем, за типом авторства та за специфікою контенту. За типом знакових систем дослідниця виокремлює текстові, фото- та відеоблоги; за типом авторства виділяє персональні та колективні. Колективні блоги дослідниця визначає як «об'єднання декількох користувачів під одним ім'ям, яке часто називають «ком'юніті» [3, с.73]. За типом контенту авторка пропонує розрізняти особисті та публічні блоги, «арт-блоги» (публікація власних робіт), дайджести (добірка чужих матеріалів за певними критеріями) та авторські журналістські блоги [3, с. 74]. Тематична спрямованість блоків - різноманітна. У професійній інтернет-журналістиці - це блоги на політичні теми, теми культури, релігії, соціального життя. Якщо ж пригадати напрями громадянської журналістики, про що ми говорили вище, - то тут блогосфера містить у собі інфотеймент, тобто розвагу інформацією, адже грома- 
дянська веб-журналістика представляє різноплановий тематичний мікс блогів: музичних, кулінарних, фешн, наукових, літературних. Власне те, що найбільш цікаве для пересічного реципієнта блогосфери.

Як ми вже зазначали вище, український професійний веб-простір теж містить чималу кількість оригінальних блогерів. Власне, блоги, що опубліковані на авторитетних сайтах, на наш погляд, містять у собі такі функції: презентації, соціалізації, соціальної активності, саморефлексії, подекуди і розважальної функції. Проте саме вони часто можуть бути джерелом фейків та неправдивої інформації, водночас зразками деструктивної дискусії та тролінгу, особливо, коли такі блоги є неприв'язаними до авторитетного веб-ресурсу, а зразком громадянської веб-журналістики.

Мультимедійно широкоформатний жанр блогу є також репрезентований у нових медіях мікроблогами. На них, зокрема, можна натрапити у соціальних мережах. Сам мікроблогінг - це є вид блогінгу, який дозволяє обмінюватись короткими текстами, фото- чи відеосюжетами. Мабуть, найбільш успішно сервісом мікроблогів користується сьогодні соціальна мережа Twitter. Саме у цій соціальній мережі можна передати свою позицію світові за допомогою короткого тексту, що не повинен перевищувати 140 символів, враховуючи пробіли [5]. Спочатку користувачі були вкрай стурбовані тим, що потрібно відмовитись від довгих блогів, проте це дозволило інформативно, лаконічно і вдало повідомляти аудиторії про певні важливі події. Саме тому мікроблогами на Twitter сьогодні користуються прес-служби багатьох українських та світових політиків (до слова, деякі політики ведуть свій твіттер-акаунт самостійно, як-от Джастін Трюдо, прем'єр-міністр Канади), поп-зірки, представників науки та мистецтва. Оскільки реципієнти інтернет-простору дедалі більше відмовляються від прочитання довгих текстів, візуально скануючи інформацію за діагоналлю чи у формі латинської літери «F», мікроблоги є вдалим виходом із поставленої проблеми. Власне, мікроблогінг у своїй сукупності дає вихід на роботу мережевого сервісу Storyfy та ще один цікавий формат жанру новини. Сам сервіс Storyfy має на меті через фрагменти різнорідного контенту створити самобутню історію. Технологія сервісу досить проста: зареєстрований користувач створює план або сценарій історії та наповнює його елементами, знайденими в мережі, різнорідними фрагментами контенту. Коли все готово, код «історії», яка є цілісним об'єктом, можна вставити в будь-яку сторінку - у блозі, профайлі соцмережі, на сайті. У сервісу є функція автоматичної агрегації інформації за певними тематичними мітками (наприклад, хештегами у Twitter), тож історія може доповнюватись сама, без участі автора [6]. Наприклад, всесвітньо відомий телеканал Аль-Джазіра для створення сюжетів у реальному часі. Наприклад, для того, щоб висвітлити тему позиції ісламу у США, журналісти ресурсу використовували чималу кількість відео з Youtube та мікроблогів із соціальної мережі Twitter. У сервісі Storyfy ми можемо також використовувати технологію тайм-лайнів. Власне, сам тайм-лайн також можна назвати своєрідним жанром нових медій, адже він дозволяє об'єднувати і творити хронологію подій у певному часовому вимірі, візуалізувати дані і передавати їх реципієнтові у доступному дизайні. На думку української дослідниці Марини Женченко, «Інтерактивний тайм-лайн - це інструмент, який допомагає проілюструвати розвиток певної події у часі та просторі. Що ви можете візуалізувати за його допомогою? Це можуть бути біографічні довідки, хронологія подій, історія певних заходів чи процесів. У тайм-лайн ви можете вбудовувати зображення, фотоматеріали, аудіо- та відеофайли, місце на 
карті (через Google Maps). Фототайм-лайни активно використовують західні медіа (Le Monde, New York Times та ін.) Також користуються стрічками часу російські і білоруські медіа, в Україні подібна практика, на жаль, не $є$ поширеною» [1]. На Заході, до прикладу, тайм-лайни використовуються не лише у журналістиці, але й в освіті. Деякі вчителі створюють такі часострічки для кращого засвоєння своїми учнями матеріалу і запропонованих тем. $Є$ чимало платформ для творення тайм-лайнів, усі вони відрізняються між собою за фінансовою моделлю (безкоштовні і платні), можливістю завантажувати файли, зовнішнім виглядом тайм-лайну.

Ми зазначали на початку дослідження, що особливість жанрової палітри нових медій - це мультимедійність. Чимало жанрів є самобутніми через технічних інструментарій, допомагає відрізнити їх від інших, а також спрямовує на урізноманітнення контенту для аудиторії. Маємо на увазі такі жанри, як стріми, онлайн-трансляції та подкасти.

Стрім - це відео наживо у реальному часі і просторі. Використання цього жанру сьогодні практично доступне кожному, хто має гаджет у кишені. Явище стрімінгу в українському медіа-просторі було найбільш популярним під час Революції Гідності, коли аудиторії просто необхідною була інформація наживо. Зрештою, саме тому, на наш погляд, настільки численними тоді були перегляди на «Громадському» $\mathrm{i}$ «Еспресо». Стрімінг - це також потужне явище у межах медіа-активізму або ж у журналістиці громадян, яка сьогодні є дедалі більше популярною. Зрештою, інструментарій соціальних мереж дозволяє використовувати явище стріму і формувати онлайн-трансляції.

Подкаст з точки зору сьогоднішніх можливостей дещо менш популярний жанр, але все ж ним користуються в мережі. Його ще можна назвати аудіо- чи візуальним блогінгом, коли у звуковому чи відеоформаті користувач мережі має можливість ділитися власною музикою, думками, позиціями, цікавою інформацією на визначену тематику.

Важливо зазначити, що представлені у дослідженні жанри нових медій є своєрідним підгрунтям для зміни формату медіа-активізму, а отже - до впровадження і популяризації громадянської веб-журналістики. Саме тому, на наш погляд, у західних медіа-дослідженнях маємо такий довгий синонімічний ряд понять громадянської журналістики: civic journalism, citizen journalism, participatory journalism, user-generated content, open journalism, pro-am journalism. Отже в українському еквіваленті відкрита журналістика чи журналістика, генерована користувачем, зважаючи на переклади з англійської вказаних вище термінів, функціонує, на наш погляд, через використання мережевої палітри у веб-просторі. До речі, в українських відповідниках є громадянська журналістика чи народна журналістика. Важливо, що журналісти вживають словосполучення громадської журналістики, ставлячи її у один синонімічний ряд із журналістикою громадян. На наш погляд, тут знову-таки варто повернутися до англомовного відповідника, за яким громадська журналістика - це common journalism, що означає журналістику громад.

Громадянська журналістика виникла у США наприкінці 80-х років XX століття як передвиборні проекти (газети «The Charlotte Observer» $\mathrm{i}$ «The Wichita Eagle»), де журналісти ототожнювали свій обов'язок із пошуком проблем виборців, а не кандидатів. Вона позиціонує себе як журналістика високої якості, розвиваючи водночас здібності громадян самостійно розв’язувати хвилюючі проблеми, зокрема, місцевого 
Лавриш Ю

рівня. Вважаємо, найкраще показати розуміння цього типу журналістики на основі досвіду медіасистеми США, де журналістика громад - це функціонування локальних медій, визначених певними культурними, етнічними і ментальними особливостями спільнот. Громадянська журналістика створює точки докладання сил, залучаючи людей і заохочуючи взаємодію між журналістами та громадянами. Вона прагне будувати двосторонню розмову з аудиторією замість однобічного інформаційного завантаження, коли на публіку обрушується безліч фактів, як це зазвичай буває у професійних ЗМІ

Громадянська журналістика має у собі чимало мотивів: по-перше, це функціонування і розвиток системи Web 2.0, по-друге, - співпраця 3 традиційними ЗМI, пропозиція контенту; по-третє, - такий напрямок роботи медій є однією із ключових умов творення громадянського суспільства, де суспільство пропонує, дискутує, критикує, а, зрештою, - творить нову інформаційну парадигму. Як приклад - минулорічні події в Україні, творення мережевих платформ «Громадського ТБ», «Спільно ТБ», «Еспресо TV». Запропоновані веб-ресурси через стрімінги з місця подій, прямі трансляції, які на той час не могли собі дозволити деякі традиційні ЗМІ, мали набагато вищий рейтинг і кількість переглядів, ніж центральне українське телебачення. Важливою i, мабуть, ключовою характеристикою громадянської журналістики $\epsilon$ оперативність і всеохопність інформації. Безумовно, це є тільки перевагою. I за такою ознакою, як оперативність, громадянська журналістика особливу конкуренцію складає друкованим ЗМІ. Адже минає не менше доби, поки журналісти друкованого видання підготують, надрукують і поширять інформацію. Громадянські журналісти не працюють за такою застарілою схемою, вони опубліковують новини в Інтернеті, тим самим забезпечуючи миттєве оприлюднення інформації. Як правило, авторами публікацій є випадкові свідки подій. Це дає підстави стверджувати, що громадянська журналістика не є спланованим проектом з чітко вибудуваною схемою, вона виникла як наслідок певних обставин та ситуацій. Отже, певна важлива подія може підштовхнути очевидця до участі у громадянському медіаактивізмі. А оперативність полягає у тому, що свідок тієї чи іншої важливої події миттєво оцінює ситуацію відповідною реакцією, тобто повідомляє про це, наприклад, у соціальній мережі. Це може бути просте коротке повідомлення, без авторських роздумів та аналізу, або ж і повноцінна стаття, з аналітикою і чіткою авторською позицією. Все залежить від бажання автора. Проте, водночас, саме це повідомлення від активного громадянина може бути платформою для дискусій у традиційних ЗМК. Тому ще однією не менш важливою особливістю громадянської журналістики є зв'язок $з$ аудиторією. У мережі зв’язок з аудиторією є значно ефективнішим. Абсолютно кожен має змогу прокоментувати публікацію, висловити власну точку зору, отримати відповідь автора. Читач має можливість доповнити чи спростувати інформацію. Важливо, що можна не тільки коментувати, але й дискутувати, доповнювати власною інформацією, а отже формувати новий порядок денний інформаційного світу. I це знову-таки спонукає урізноманітнювати не лише контент, але й жанрову палітру нових медій. Основою громадянської журналістики є добровільне бажання громадянина поділитися актуальною та, на його думку, цікавою інформацією, хоча трапляються фейкові повідомлення в мережі, тому професійним ЗМК все ж варто не повністю довіряти активним громадянам, а верифікувати дані. 
Сьогодні можемо назвати такі форми громадянської журналістики: аканти/групи/сторінки у соціальних мережах, відео/фото на платформах YouTube чи Instagram, творення окремих веб-ресурсів (наприклад, українські зразки - сайт «Майдан» чи «ХайВей»), окремі рубрики-колонки на суспільно-політичних сайтах («Народна правда» - «Українська правда»; «Я-Кореспондент» - «Кореспондент», «I-Report» сайт $\mathrm{CNN}$ ), блогінг. I знову-таки саме у цих форматах заначених ресурсів використовують мікроблоги чи блоги, стріми, лонгріди.

Отож, якщо підсумувати сказане вище, можна дійти до таких висновків:

- По-перше, жанрова палітра нових медій дозволяє урізноманітнювати формати подання інформації за допомогою цифрового інструментарію;

- По-друге, практично всі зазначені жанри є поштовхом до розвитку журналістики громадян, де автором інформаційного чи аналітичного повідомлення $\epsilon$ не професійний журналіст, а пересічний користувач мережі;

- По-трете, жанри нових медій дозволяють вільно висловлюватися кожному, без цензурування редактора, як би це було у традиційних редакціях;

- По-четверте, глобально такі зміни у пріоритетах медіа-світу впливають і на демократичні процеси у суспільстві.

\section{REFERENCES}

1. Женченко М. «Динамічна візуалізація: інтерактивні тайм-лайни в нових медіях»// Медіакритика. Info - [Електронний ресурс] - Режим доступу: http://www. mediakrytyka.info/onlayn-zhurnalistyka/dynamichna-vizualizatsiya-interaktyvnitaym-layny-v-novykh-mediyakh.html

2. Потятиник Б. В. Інтернет-журналістика : навч. посіб. / Б. Потятиник. - Львів : ПАІС, 2010. $-246 \mathrm{c}$.

3. Прудкая Н. Блог в системе социальных отношений / Н. Прудкая // Интернет и интерактивные электронные медиа : исследования. Сборник лаборатории медиакультуры, коммуникации, конвергенции и цифровых технологий. - Ч. ІІ. Блоги в системе массовых коммуникаций. - М. : Изд-во МГУ, 2007. - С. 59-88.

4. Романюк В. Стан громадянської журналістики в Україні - дослідження / В. Романюк, М. Довженко. - Львів: Школа журналістики УКУ, 2015 - [Електронний pecypc] - Режим доступу: http://journalism.ucu.edu.ua/program-highlights/4739/

5. Что такое Twitter? Особенности работы с сервисом Твиттер// Databy.com - [Електронний ресурс] - Режим доступу: http://databy.com/twitter/1246-chto-takoe-twitterosobennosti-raboty-s-servisom-tvitter.html

6. Як розповідати історії за допомогою Storify// Медіаграмотність - [Електронний pecypc] - Режим доступу: http://osvita.mediasapiens.ua/web/online_media/yak rozpovidati istorii za dopomogoyu storify/ 


\title{
NEW MEDIA GENRES: SPECIFICATION AND CREATIVITY
}

\author{
Yuliana Lavrysh \\ Ivan Franko National University of Lviv, \\ Generala Chuprynky Str. 49, 79044, Lviv, Ukraine \\ e-mail: newmedialnu085@gmail.com
}

This publication presents a variety of genres of new media, analyzes the tools and effectiveness of genres in creating a format for civil journalism and democratization of media space.

Traditional journalism has many opportunities for processing and transmitting information. If we work textually with a specific theme, then we use genres that best help to realize the journalist's goal. Digital capabilities allow for the specific presentation and processing of information. The new media represents the transformation of the old and usual approaches that we have become accustomed to using in traditional media, adding opportunities to work even better with text, sound, video, representing the multimedia space, and at the same time measuring the presentation of the person who seeks to share his information with the world. Again, digital capabilities made it possible to formulate distinctive genres of new media, some of them transformed from traditional genres. During our research, we had a focus on the advantages and disadvantages of each genre of new media.

First of all we concentrate our attention on blog like a leading genre in new media space. In general, the main features of the blog are the author's and subjective nature of information, uniqueness, style, chronological distribution of publications, interactivity, accessibility to a wide audience, periodic updates. These properties are inherent to all blogs in general, and each of the types has its own peculiarities of functioning.

In addition, we analyzed the timeline, stream, podcast, and online broadcasts and analyze the impact of these genres on democratization of society.

Key words: new media genres, blog, timeline, stream, podcast. 